is not, however, the one noted by Coquillet (l. c.) but an entirely new species.

$$
\text { Carleton R. Ball, }
$$

Agronomist in Sorghum Investigations

U. S. Department of Agriculture,

Washington, D. C.

\section{TWELFTH ANNUAL MEETING OF THE NATIONAL ASSOCIATION OF STATE UNIVERSITIES}

THe twelfth annual meeting of the National Association of State Universities was held in Washington, D. C., on November 18 and 19, 1907. In this association upward of forty universities are entitled to membership and thirty-nine are active members; thirty-five universities were represented at the meeting. It was one of the most important meetings of the association ever held in point of attendance, bearing of the topics discussed, business transacted, and investigations ordered.

The president's address, "Some Problems of American Universities," gave a comprehensive view of the field of higher education in. America and suggested many vital topics for possible future investigation. The question of a "National University" was again to the front and a definite scheme was endorsed for a non-degree-conferring institution that should add to research opportunities several unique practical functions. A committee of the association in conjunction with a committee of the National Educational Association is charged with the duty of presenting the plan to Congress. A committee met the trustees of the Carnegie Foundation and further discussed the claim of the state universities to the benefits of the retirement fund. At this writing the question is still open. Moreover, a committee on "standardizing" American universities was appointed. This question involves the vital and difficult problems of reorganization of higher education and the action of the association may be of far-reaching importance.

Among the many other questions discussed were "Development of Graduate Schools in State Universities" and "Preparation of High School Teachers."

The Secretary of the Interior and the Com- missioner of Education attended part of the meetings and evinced a helpful interest in the problems before the association. A reception was given by the president and faculty of George Washington University.

The relation of state universities to the educational interests of each state, the efficiency of the organization and its representative character make the American Association of State Universities a ruatural leader in discussing some of the many problems of higher education which are pressing for solution.

JAMES H. BAKER,

President of the Association for 1907

UNIVERSITY OF COLORADO

\section{THE AMERIOAN SOCIETY OF AGRONOMY}

THE American Society of Agronomy was organized in Chicago on December 31, 1907. According to the constitution, the object of the society shall be the increase and dissemination of knowledge concerning soils and crops and the conditions affecting them.

It is expected that the membership will be composed largely of scientific workers in agronomy. A strong feeling has been prevalent for some time that an opportunity is greatly needed for college and station men to meet and discuss methods of experimentation and instruction in agronomy.

Provision has been made for including as charter members all who join the society before July 1, 1908. Arrangements were also made by which local sections may be established in any part of the country on application of three members of the society. The agricultural colleges may thus have local organizations for discussion of agronomic subjects.

By resolution the society expressed its desire to assist the Society for Promotion of Agricultural Science in bringing about affiliation of all the scientific agricultural organizations.

The officers for the present year are as follows:

President-M. A. Carleton.

First Vice-president-C. P. Bull.

Second Vice-president-J. F. Duggar.

Secretary-T. L. Lyon.

Treasurer-E. G. Montgomery. 